\title{
Why you need a lawyer
}

\author{
Craig Shimasaki
}

What's involved in formally starting a biotech company?

\begin{abstract}
reating a sustainable biotech company is $\bigcup_{\text {analogous to driving from New York City }}$ to Los Angeles. There are myriads of routes to get there, but if you start out heading north, you will never arrive. More to the point, if you're headed north and not legally licensed to drive, not only will you fail to reach your destination but you may also experience disastrous consequences.

For would-be entrepreneurs, establishing a venture as a legal entity is the key first step in making the business a reality and moving it forward. This article summarizes the key tasks in legally founding your company and outlines the different types of legal expertise you will need to recruit. Doing this correctly at the beginning will pay dividends in terms of your ability to attract capital, align business and scientific goals, and set your company on the path to success.
\end{abstract}

\section{The legal team}

So you have a concept for your new venture. Your first step in making it a reality is to find a great attorney. You might ask, "Why do I need an attorney? Aren't there legal forms available online that can save me a lot of money?" Yes, there are, and in fact most attorneys use their own boilerplate documents. But when you hire an attorney, you are paying for experienced legal advice and business guidance - not for someone who fills out forms.

You should consider your attorney the most critical employee for your budding organization because his or her counsel and advice will directly impact the direction you take in corporate and financing matters. For instance, your attorney will advise you on the impact of terms for founders' agreements, your strategy for issuing stock options, the implications of tax law, and securities and financing

Craig Shimasaki is CEO of BioSource

Consulting, Oklahoma City, USA.

e-mail: cs@biosourceconsulting.com

\section{Box 1 Count the costs}

Legal expenses are typically greater than you might anticipate, but getting your business established correctly will save you major headaches later. Depending on their experience and locale, corporate attorney rates for biotech startup expertise can range from $\$ 200$ to more than $\$ 750$ per hour. All attorneys should give a complimentary initial visit to discuss your situation. If they insist on charging you for an initial consultation, find another attorney.

Getting your company established and drawing up founder and employee documents and a license agreement can cost $\$ 5,000-\$ 25,000$ or more. Cost depends on the complexity of your business, the number of founders and the issues related to a technology license.

Legal assistance for closing a round of capital can be $\$ 10,000-\$ 50,000$ or more depending on the size of the round, the number of investors and other terms related to funding. Your attorney should provide you with a good estimate before beginning any transaction, and some may even give you a flat rate if the work is clearly defined. For larger deals, such as closing on a venture capital round of financing, you may be able to get a commitment for a maximum limit on legal fees. Some attorneys that specialize in startup organizations may even accept deferred compensation but may charge a higher fee and take a small equity position.

issues. Your attorney will also give you advice on the best practices in intellectual property (IP) protection, how to interpret employment law matters and how best to structure various contracts and agreements.

The truth is, the biotech entrepreneur will need help from three types of attorneys: corporate, patent and securities. When establishing a company, you should first retain a corporate attorney.

A corporate attorney specializes in corporate and business matters for biotech startups and practices business law. He or she should be experienced in startup issues, such as organizational structure, employment agreements, stock options and financing structures-particularly venture capital deals.

You will also need a patent attorney who specializes in patent law and biotech patent prosecution-litigation in particular. Make sure this person understands your technology area. Look for a patent attorney with a combined background or dual degree in the area of your technology, such as someone with a JD and a $\mathrm{PhD}$ or ChemE. These individuals provide added value because they understand the science and can add to the patent in ways that only an experienced scientist can.

During the early stages of your organization one of the most valuable assets you have is your IP, so be sure that it is managed well. If you are the inventor, you already have a working relationship with a patent attorney. If you licensed IP from an institution, your patent portfolio is already being managed by a patent attorney. However, be sure you are confident with the capabilities of this person-or find another.

The final type of legal expertise you'll require is a securities attorney. This person specializes in the legal aspects of acquiring funding, handling private placements and dealing with securities laws. He or she will provide guidance on many issues related to raising capital and will be sure that you are complying with securities laws and protecting the company's interests as you raise money. Occasionally, you may be able to locate a good corporate attorney who is also experienced in securities.

Finding the right attorney is probably easier said than done, as it's unlikely you'll know experienced biotech attorneys when first starting your firm. One of the best ways 


\section{Box 2 Changing names}

There are certain situations in which you might want to consider changing an established company name. Here are some examples:

- If the company has a troubled past that haunts the new management as it tries to raise money, or if you are reorganizing the company or doing a restart.

- If the name is a source of confusion because it was strongly associated with a former focus and the company has a new focus.

- If the previous management had a notorious reputation and a clear separation is needed.

- If the current name is problematic for business because it ties the company to an unrelated field.

to find one is through networking-start by asking other biotech entrepreneurs who they would recommend. Search for reputable law firms specializing in startup biotechs in your area. You should try to find an attorney with offices in your city because you don't want to be boarding a plane just to have a face-to-face meeting. But if you don't live in a biotech hub, you may have no other option than to hire an attorney who does. Long-distance travel isn't optimal; however, a lawyer living in a biotech hub can provide advantages: these experienced lawyers usually have venture capital contacts and access to seasoned biotech executives, which can help with financing and recruiting.

Ideally, you will want to work with an attorney who is a partner or senior member in a smallto medium-sized law firm-this is preferable to working with less-experienced junior staff at a mega law firm. Of course, your fees will be higher working with a senior partner, but you get what you pay for (Box 1).

\section{Establishing your company}

Before you incorporate your company you need a name that brands the company and its future. Barring anything unforeseen (and usually bad), you'll keep that name for the life of the company (Box 2). There are at least four aspects to consider when choosing a company name: does it represent the current and future focus of the organization, is it relatively easy to pronounce and recognize, is it unique enough that it will not be confused with the names of other organizations and will it work well with envisioned products? There are, of course, other issues to think about, too (Nat. Biotechnol. 28, 16-19, 2010).

After selecting a company name, the next step is to formally incorporate and set up a legal structure. This allows for the issuance of stock to potential investors, founders or future employees and it reduces your exposure to liabilities and protects personal assets. But it also provides maximum advantage of tax laws, including carry-forward losses for the business.

Another important decision is the choice of corporate structure, which should be discussed with your attorney and will be based upon your current plans and future direction. There are five corporate structure options in the US: sole proprietorship, partnership, limited liability corporation (LLC), S corporation (S-corp) and $\mathrm{C}$ corporation (C-corp). In the UK, there are also limited (Ltd.), public limited (PLC) and unlimited corporations.

The selection of your legal structure impacts how the business is taxed and sets differences in liabilities to the owners and fiduciary agents of the company. Some startups may begin as an LLC until they get significant investments. However, because we are talking about a biotech company, ultimately any enterprise in the US will need to be a C-corp, which is this industry's standard business entity because of laws pertaining to ownership, structuring flexibility, finances and taxation.

When incorporating a business, your attorney files the company's articles of incorporation and bylaws. This filing designates the number of authorized company shares, the number of board members and other related matters. Your state of incorporation can be where you are actually located, but before you secure venture or institutional capital, you'll likely need to be incorporated in Delaware, where corporate laws and tax laws are more favorable. Your attorney can handle this.

\section{Issuing stock}

Next, your corporate counsel will assist with issuing stock or stock options to the founders, inventors, IP holders and key staff. You should issue stock soon after the organization is established rather than waiting until after capital is raised. When shares are issued upon company formation, they can be granted to the founders at minimum value. If stock is issued after raising a significant amount of capital, there is a specific value imputed to the enterprise. If shares are issued at a discount to that value, the shareholder could have large tax consequences.

For instance, upon securing investor financing there is a 'fair market' value imputed to company shares based on the amount that investor paid. If shares are simultaneously discounted to founders or key employees, there could be a tax liability based on the difference between the fair market value and the amount of money these founders paid for their stock. There is no reason for founders or key employees to be paying taxes on shares at this stage of the company. Your attorney will guide you through any tax consequences of issuing stock or obtain the help of tax counsel.

Your corporate attorney should also give advice on what types of stock to be issued, choosing from founders' stock, restricted stock, preferred shares, common shares, voting and nonvoting shares, and two kinds of stock options: incentive stock options (ISOs) and nonqualified options (NQOs). These all have different privileges, rights and restrictions. Vesting schedules are usually given with stock options (NQOs and ISOs) and restricted stock. If this is all sounding foreign to you, then you're beginning to see why hiring an attorney is one of the first things you should do.

Many biotech companies are formed by more than one founder, and they all usually receive founders' shares. It's tempting to equally divide allotted shares among each founder, but you should first consider what each individual has contributed to establishing the company and what their roles will be going forward. Will they all be working full time? And are they all committed to sticking around to see it through to success?

The answer to these questions will help determine the split of founders' shares. You'll also need a founders' agreement that outlines the provisions and considerations given in exchange for work, contribution and IP rights. This document should include a provision that the company can buy back a certain amount of its shares should one of the founders later leave the organization. This prevents a founder who leaves from watching his or her shares rise in value on the labor and sweat of others.

Beyond that, there are several other agreements needed for founders and employees alike (Box 3).

\section{The board}

Your articles of incorporation will stipulate that you set up a board of directors. This group has a legal obligation to the company in that they possess a fiduciary (trustee) responsibility to look after the best interests of the overall organization. You and your shareholders elect the board (even if, at startup, the shareholders are just you and a few angel investors).

Carefully select board members based on expertise and ability. Do not include friends and family unless they are actually qualified and even then be aware of the pitfalls. Remember that difficult issues are decided by the board 
and you do not want personal relationships influencing decisions.

The board has two main duties. The first is called 'duty of care', meaning it has an obligation to make decisions in a reasonable, careful and prudent manner. All decisions have risk, and any decision can be second guessed, but if the board made a rational decision that's considered judicious at the time, it has operated under the duty of care.

The second is the 'duty of loyalty', meaning all decisions or transactions with and for the company must not be motivated by self-dealing or any conflict of interest. If a conflict arises, that board member should disclose it and abstain from voting on that particular issue.

A board needs a chairman, and if the CEO is not the chairman, it's usually a board member appointed by the major shareholders (investors or otherwise). If you are fortunate enough to have good venture capitalists with depth of experience in your field, they will guide and strengthen the remaining board member selection.

Odd numbers of board members are chosen to avoid voting logjams, and your board should grow in size as the company grows. In the beginning, the board may consist of only three members. Later, it may grow to five or even seven. A publicly traded biotech company may have nine to eleven members, but it is always advantageous to have fewer instead of more.

Board members that are investors or executives of the company are not usually compensated for their participation as they are simply managing their investment. As the company grows and independent board members are added, board compensation is usually a mix of cash, such as an annual retainer, and some form of equity compensation.

Depending on the stage of the company, the compensation may simply be reimbursement for out-of-pocket expenses or may be up to several thousand dollars annually. Generally, equity compensation for directors is given as stock options, though it can also be in other forms of stock, as discussed previously. The amount of stock may be between $0.25 \%-2 \%$ of outstanding shares or more depending on the value of these members to the organization.

\section{The SAB}

The scientific advisory board (SAB) is called upon for advice and assistance in matters pertaining to the science. An SAB should be formed early and should be selected based on expertise and knowledge in the technology

\section{Box 3 The dotted line for all}

These are some typical agreements that cover founders and employees, and they protect intellectual property (IP) assets and provide the assurances that are expected by any new investor in the company.

Confidential Disclosure Agreement or Nondisclosure Agreement. This protects the company by requiring that each employee appropriately handle confidential information. By doing this, the company protects its know-how and IP from competitors.

Invention Assignment Agreement. This transfers assignment of any and all new inventions conceived by the employee to the company. This ensures that the organization owns the IP required to develop and market its products. There are allowances given for inventions before hire.

Non-compete Agreement. This prevents an employee from quitting and starting an identical business in the same field using the same technology. It protects the company from disgruntled founders or key employees going out and starting a competitive business with the information they have been using in your company.

Employment Agreement. This contains any other provisions that constitute employment, especially for those who may be considered key employees; these provisions may be combined with the other agreements.

or science of the company-these individuals should be considered experts by their peers.

An SAB is not a legally constituted board, and its members do not have fiduciary responsibilities. For that matter, this group could be called a scientific advisory committee if preferred. The number of SAB members will vary, though three to seven is usually sufficient. Have your corporate attorney provide a thorough $\mathrm{SAB}$ agreement, which contains member duties, type of compensation, a confidential disclosure or nondisclosure agreement, and specifications about publications and inventions.

A secondary purpose of the $\mathrm{SAB}$ is to bolster credibility for your company's science. Individuals considered experts in your field indirectly give credibility to the business venture and are reassuring to potential investors.

The $\mathrm{SAB}$ members should be willing to present reports on the scientific progress at conferences. Using SABs in this manner can also accelerate acceptance of the company's work in the eyes of future investors. Having an SAB co-author peer-reviewed publications shows its involvement in and contribution to developing the science.

Like the board of directors, the SAB is typically compensated with either stock options or restricted stock. The amount of stock options granted varies depending on the company and the critical need of each individual. Ranges for stock options can include $0.1 \%-2 \%$ of outstanding shares. Ranges for restricted stock can be $0.1 \%-0.5 \%$ of outstanding shares. If your members are highly sought after, sometimes you may need to pay a per-meeting fee or nominal annual retainer to the $\mathrm{SAB}$ at early stages. However, it is not unusual to just provide equity and cover out-of-pocket expenses that members incur to attend SAB meetings. After laterstage funding, you may add an annual retainer or a per-meeting fee when the finances of the company can support this.

\section{Conclusions}

The importance of a good attorney cannot be overstated. I have observed potential investors walk away from investing in an organization because of sloppy corporate structure, missing employment and IP agreements, or convoluted and overly complicated licensing agreements. Investors need to have confidence in the management's ability to run an organization before they will invest.

You don't want to learn later that the optimal route was not taken for your company's development or that critical agreements were not drafted appropriately. Setting a solid legal framework with appropriate and detailed contracts, licenses and agreements gives new investors confidence and is a key first step to setting the foundation for your business' future success. 